\title{
Intertekstualitas dalam Puisi Arab: Puisi al-Ḥallāj dan Fārūq Juwaydah
}

\author{
Sammad Hasibuan* \\ Universitas Islam Negeri (UIN) Sunan Kalijaga, Yogyakarta, Indonesia
}

\section{Intertextuality in Arabic Poems: Poems by al-Ḥallāj and Fārūq Juwaydah}

\section{E-Mail Address}

Sammadhasibuan@gmail.com

*Corresponding Author

\section{Keywords}

Arabic poems;

al-Ḥallāj;

FārūqJuwaydah

Intertextual

\begin{abstract}
This study aims to reveal the intertextual found between al-Halläj's poem (qașidah) and Faruq Juwaidah's wa Täba al-Qalb poem. In this case, it refers to the basic assumption of intertext studies, namely that the texts or works that appear today are inseparable from the influence and role of the works that previously existed long before. Furthermore, in intertextual studies, old works that are used as a reference in making new works are called hypograms, while new works written by new authors that appear later are called transformational works. The method in this research is using descriptive analysis method. While the approach used is intertextual. Based on the results of the intertextual analysis conducted by researcher on qașidab al-Hallāj and wa-Täba al-Qalb poem, the researchers found (1) wa-Täba al-Qalb poem is a form of transformation of qașidahalHallàj, (2) wa-Tāba al-Qalb poem is the response from qașidah al-Halläj. The results of this study indicate that the impact or influence of old literary works on those that emerged later was very strong.
\end{abstract}

\section{Pendahuluan}

Penelitian ini mengkaji intertekstual puisi (qașidab) al-Hallāj dengan puisi wa-Tāba al-Qalb karya FārūqJuwaydah. Kedua karya tersebut seolah terjadi dialog antara satu sama lain di mana puisi Fārūq menjadi jawaban dari puisi al-Hallāj. Padahal, kedua karya tersebut ditulis dalam kurun waktu yang berbeda. Sekilas tentang al-Hallāj, ia merupakan sosok sufi yang menggegerkan kalangan ulama fikih karena pernyataannya "Anā al-Haqq" (Akulah kebenaran) yang menyebabkan hidupnya harus berakhir di tiang gantungan (Ansari, 2000). Sufi agung kelahiran Persia itu telah lama berangkat menuju laut keabadian melalui pintu tragedi yang begitu mengerikan, yaitu melalui tiang gantungan oleh kekuasaan yang kejam (Syafi'i, 2003). Versi lain menyebutkan bahwa sebab dibunuhnya alHallāj bukan karena perbedaan pendapat dengan kalangan ulama fikih, melainkan ia dituduh memiliki hubungan dengan gerakan Qarāmițah (Hamkah, 2018). al-Hallāj dihukum mati berdasarkan fatwa al-Qāḍi Abū 'Umar dan para fukaha lainnya. Peristiwa itu terjadi pada masa pemerintahan Khalifah al-Muqtadir Billāh, khalifah kesembilan dari Dinasti 'Abbāsīyah (Taufiq, 2014). 
Al-Ḥallāj yang memiliki nama lengkap Abū al-Mughīth al-Husayn Ibn Manșūr al-Bayḍawī ini lahir sekitar tahun $244 \mathrm{H}$ di al-Bayḍā', Persia. Digelari al-Hallāj karena penghidupannya ia peroleh dari memintal kain wol (Mukarromah, 2015). Sumber lain mengatakan, ia digelari al-Hallāj karena ayahnya merupakan seorang pekerja yang membersihkan kapas dari bijinya (ballāj) ('Uyūn al-Sūd, 2013). Dalam puisinya-yang dijadikan sebagai objek penelitian ini-melukiskan seruannya untuk mencintai Tuhan, dan teguran kepada manusia-manusia yang melupakan eksistensi Tuhan dan melakukan perbuatan dosa. al-Halläj menegaskan bahwa seseorang jangan merasa enteng setelah melakukan sebuah kemaksiatan atau perbuatan dosa, sebab perbuatan mereka selama di dunia akan diminta pertanggungjawaban di akhirat.

Teguran yang diungkapkan oleh al-Hallāj dalam puisinya lalu dibalas dan direspon oleh seorang penyair berkebangsaan Mesir bernama FārūqJuwaydah melalui puisinya wa-Tāba al-Qalb (dan hati itu telah bertaubat) yang muncul sepuluh abad kemudian. Wa-Tāba al-Qalb adalah sebuah judul puisi yang masuk dalam antologi $F_{\bar{\imath}}$ 'Aynayki 'Unwānī yang diterbitkan pada tahun 1979. Secara garis besar, substansi dari puisi tersebut berupa respon atas seruan dan teguran al-Hallāj. Respon Fārūq terhadap puisi al-Ḥallāj adalah bahwa manusia sudah sepatutnya menyadari akan kebutuhan mereka terhadap Tuhan. Manusia adalah makhluk yang suka melakukan dosa. Akibat dosa yang terlalu banyak, manusia akan gelisah. Oleh karena itu, untuk meminta pengampunan, manusia harus bertobat dan meninggalkan segala perbuatan maksiatnya.

Dalam pandangan teoritikus sastra modern, sebagaimana yang diuraikan oleh Marshall, semua teks, baik yang berorientasi sastra atau sebaliknya, tidak memiliki makna yang independen. Akan tetapi, terdapat relasi antara teks baru dengan teks sebelumnya. Dalam teks-teks sastra, sastra lama memiliki pengaruh terhadap karya sastra modern yang membantu pengarang dalam pengambilan tema, penokohan, motif, dan sebagainya. Karena pengaruh dalam penciptaan karya tersebut, sering terjadi hubungan intertekstualitas dalam karya sastra (Abdullah, 2009; Muzakka, 2018). Interteks dapat muncul dalam sebuah karya sastra dalam bentuk interaksi yang berbeda. Salah satunya adalah karena interaksi agama (Albay \& Serbes, 2017).

Intertekstual (intertextuality) merupakan istilah yang pertama kali diperkenalkan oleh Julia Kristeva. Hubungan antarkarya tersebut dapat berupa hubungan persamaan atau pertentangan. Ketika seorang pengarang menulis teks kesastraan, di masyarakat tempat pengarang itu tinggal, pasti sudah ada tradisi, konvensi, folkore, folktales, atau bahkan teks-teks tertentu yang mungkin juga berupa teks kesastraan yang kemudian dijadikan semacam pijakan dalam penulisannya (Faruq, 2016). Pengarang ketika mengekspresikan karyanya, telah meresepsi karya sebelumnya. Hanya saja, terjadinya interteks tersebut ada yang sangat vulgar dan ada pula yang sangat halus. Semua kasus interteks tergantung keahlian pengarang menyembunyikan, atau sebaliknya, memang ingin menampakkan karya orang lain dalam karyanya (Endraswara, 2011).

Intertekstual merupakan konsekuensi dari aspek psikologis yang dipengaruhi oleh pengalaman nenek moyang. Pengalaman bersama antara manusia ini merupakan sumber seni yang hebat bagi penciptanya dan merupakan penyebab bagi penerima untuk menikmatinya (Madās, 2004). Dalam interteks, penulis karya baru melakukan semacam transformasi pada karyanya. Namun demikian, pembaca atau peneliti masih dapat menemukan persamaan atau pun perbedaan yang tertuang di dalam karya baru itu, mengingat bahwa karya sastra adalah karya kreatif yang menghendaki adanya kebaruan. Namun demikian, tentu tidak baru sama sekali. Sebab, bila sama sekali menyimpang dari 
konvensi, maka ciptaan itu akan tidak dikenal atau pun tidak dapat dimengerti oleh masyarakatnya (Pradopo, 2019).

Intertekstual, menurut Muhammad al-Za'bī, adalah sesuatu yang memuat teks sastra, baik teksteks maupun gagasan lain sebelumnya, dengan metode kutipan, penyertaan, rujukan, atau metode lainnya dari teks atau bacaan budaya. Teks atau gagasan tersebut menyatu dengan teks asli untuk membentuk teks baru yang terintegrasi dengan teks sebelumnya (al-Ni‘āmī, 2012). Mohamed Moftah menyebut intertekstual berupa korelasi antarteks lama dan baru yang tentunya dalam aspek kualitas yang berbeda. Sementara itu, Robet Schulz membedakan intertekstual dengan kritik antarteks. Teks yang dimaksud di sini bukan hanya teks lisan atau teks tertulis, melainkan teks dalam pengertian yang lebih luas (Mousa, 2013). Dunia semesta ini pun dapat dikatakan sebagai teks. Adat istiadat, kebudayaan, film, drama secara pengertian umum juga disebut teks (Jabrohim, 2016).

Irwin (dalam Batmang 2019) mendefinisikan intertekstual sebagai pembentukan makna teks berdasarkan teks lain yang dapat merujuk pada peminjaman dan transformasi teks terdahulu atau rujukan pembaca dari teks satu dalam membaca teks lain. Kajian ini dikenalkan pertama kali oleh Julia Kresteva sebagai pengembangan dari teori sastra dialogisme pendahulunya, yaitu Mikhail Bakhtin, seorang pemikir Rusia. Kristeva menyebut tiap teks merupakan mozaik kutipan-kutipan dan merupakan penyerapan (transformasi) teks-teks lain. Maksudnya, tiap teks itu mengambil halhal yang bagus dan diolah kembali dalam karyanya atau ditulis setelah melihat, meresapi, dan menyerap hal yang menarik. Kristeva menambahkan bahwa setiap teks lahir sebagai hasil daripada menguti, memodifikasi, mentransformasi dan meresapi teks-teks lain (Ratih, 2017; El Shirazy, 2014).

Interteks dapat dilakukan antara novel dengan novel, novel dengan puisi, novel dengan mitos. Relasi antara teks ini tidak terbatas dalam hal persamaan, tetapi bisa juga sebagai pertentangan, baik sebagai parodi maupun sebaliknya sebagai negasi (Ratna, 2019). Abdullah (2009) menguraikan tiga cara kerja intertekstual, yaitu pertimbangan (deliberation), penyerapan (absorption), dan dialogisme (dialogism). Pertimbangan adalah proses menulis teks dengan kesadaran teks lain. Penyerapan adalah proses menulis ulang teks yang tidak terlihat sebagai komponen alami dari teks yang baru. Sementara itu, dialogisme adalah proses mendistorsi atau mengubah teks yang tidak terlihat dan mengabaikan kesucian teks asli. Dari proses interteks tersebut, setidaknya teks baru akan menyentuh teks lama dilihat dari beberapa level yang meliputi kiasan artistik, gema dan kutipan, ekspresi budaya, hubungan artistik, kecenderungan sosial-politik, atau kecenderungan filosofis-religius.

Menurut Riffaterre, konsep terpenting dalam teori interteks adalah hipogram (bypogram) yang telah dikenal dalam tradisi Saussurean. Hipogram adalah karya sastra terdahulu yang dijadikan sandaran berkarya (Ratna, 2019). Menurut Endraswara (2011), terdapat empat bentuk hipogram, yaitu (1) ekspansi, berupa perluasan atau pengembangan karya; (2) konversi, berupa pemutarbalikan hipogram atau matriksnya; (3) modifikasi, berupa perubahan tataran linguistik, manipulasi urutan kata dan kalimat; dan (4) ekserp, berupa semacam intisari dari unsur atau episode dalam hipogram yang disadap oleh pengarang.

Untuk membedakan penelitian ini dari penelitian sebelumnya, maka perlu kiranya diuraikan beberapa telaah pustaka yang mengkaji karya puisi FārūqJuwaydah. Satu di antaranya, Narjes Ansari (2016), yang berjudul "Shi'r Fārūq Juwaydah: Dirāsah Uslūbīyah fī Shi' rih al-Multazam”. Penelitian tersebut mengkaji puisi FārūqJuwaydah dengan pendekatan stilistika (uslūbìyah), yakni suatu kajian yang melihat unsur-unsur keindahan bahasa yang digunakan dalam karya sastra, termasuk puisi. Hasil dari penelitian ini mengungkapkan jika Fārūq merupakan seorang penyair militas Mesir yang 
dapat membuat puisi pedas sekaligus tajam dengan tujuan untuk membela tanah airnya. Hal itu dapat dilihat dari caranya menggunakan elemen-elemen gaya yang berbeda antara dialog dan cerita agar dapat merepresentasikan keinginan pribadinya. Selain itu, repetisi yang seringkali muncul bertujuan untuk menarik perhatian, sebab melalui repetisi itulah Fārūq menegaskan makna atau gagasan yang ingin diutarakannya.

Zohreh Naemi \& Saeed Zarmohammadi (2014) yang berjudul "Tajalliyāt al-Muqāwamah alFilisțīnīyah fî Shi'r Fārūq Juwaydah”. Penelitian ini menyimpulkan bahwa sebagian puisi Fārūq Juwaydah masuk dalam kategori puisi perlawanan atau pembebasan. Fārūq seringkali menyuarakan tentang pembebasan Palestina dari penjajahan bangsa Yahudi. Karena ia seorang yang beragama Islam, maka ia merasa sebuah keharusan dalam membela Palestina dari rongrongan Yahudi. Selanjutnya, penelitian Ali Khezri \& Mounira Hamdi (2020) yang berjudul "Tajalliyāt alnustūlūjīyah wa-ẓawāhiruhā fī shi'r Fārūq Juwaydah” Penelitian ini mengkaji aspek-aspek nostalgia yang tertuang dalam bentuk puisi kontemporer Mesir yang digubah oleh FārūqJuwaydah. Nostalgia dalam puisi Fārūq adalah pengingat kenangan masa lalu yang indah, cinta dan perpisahan dengan kekasih, idealisme, nostalgia politik, kesedihan yang menua, dan lain sebagainya. Dari keseluruhan tema-tema puisinya, cinta dan kecintaan tanah air lebih mendominasi.

Kemudian, penelitian Kobra Roshanfar \& Sayyidah Akram Rakhshadehnia (2010) yang berjudul "Qinā' al-Hallāj fī al-Shi'r al-'Arabī al-Mua'ṣir: Șalāh 'Abd al-Ṣabūr wa-'Abd al-Wahhāb alBayātī Numūdhajān”. Penelitian ini mengkaji tentang pengaruh al-Hallāj terhadap para penyair modern. Hasil penelitian ini menyimpulkan, meskipun terdapat pro-kontra dalam memahami akidah dan interprestasi puisi-puisi dan perkataannya, al-Hallāj masih tetap memiliki citra positif di kalangan penyair Arab modern. Dalam pandangan mereka, al-Hallāj merupakan simbol kebebasan, keselamatan, perjuangan melawan tiran, dan dalam setiap kasus itu ia adalah simbol seorang intelektual yang tertindas. Dalam drama 'Abd al-Ṣabūr, ia mengadopsi perkataan, pemikiran al-Hallāj tentang tasawuf. Pengadopsian tersebut dapat dilihat dari judul dan fitur metafora yang digunakannya. Begitu juga dengan 'Abd al-Wahhāb al-Bayātī, ia banyak menggunakan kosakata dan ungkapan yang mengadung unsur-unsur tasawuf. Keduanya juga menggunakan unsur-unsur dialog sebagaimana yang digunakan oleh al-Ḥallāj, terutama dalam drama 'Abd al-Ṣabūr,

Berdasarkan kajian terdahulu, penelitian intertekstual puisi al-Hallāj dan puisi wa-Tāba al-Qalb karya Fārūq Juwaydah belum pernah dilakukan sama sekali. Hasil penelitian ini diharapkan mampu menjadi sumbangsih keilmuan, terutama dalam kajian intertesktulitas karya sastra.

\section{Metode Penelitian}

Metode yang diguanakan dalam penelitian ini adalah deskriptif-analitik. Metode deskriptif-analitik dilakukan dengan cara mendeskripsikan fakta-fakta yang kemudian disusul dengan analisis (Ratna, 2019; Sholihah \& Kaulin, 2017). Adapun umber data dalam penelitian ini adalah qașidah al-Hallāj dan puisi wa-Tāba al-Qalb karya FārūqJuwaydah. Data-data yang memiliki hubungan di dalam dua sumber tersebut kemudian dianalisis menggunakan pendekatan intertekstual untuk menemukan persamaan maupun perbedaan di antara keduanya. Pendekatan intertekstual dimaksudkan sebagai kajian terhadap sejumlah teks kesastraan yang diduga mempunyai hubungan bentuk-bentuk tertentu. Hal itu dilakukan dengan menemukan unsur-unsur intrinsik seperti ide, gagasan, peristiwa, plot, penokohan, gaya bahasa, dan lain-lain di antara teks yang dikaji. Dengan penelitian interteks 
demikian, akan terlihat lebih jauh bahwa karya berikutnya merupakan respon terhadap karya-karya yang terbit sebelumnya (Endraswara, 2011).

\section{Hasil Penelitian dan Pembahasan}

A. Teks Puisi al-Hallāj dan Puisi Wa-Tāba al-Qalb Fārūq Juwaydah

Teks puisi al-Hallāj ini diambil dari kitab Sharḅ Dīwān al-Hallāj yang disunting oleh Kāmil Muṣtafá al-Shaybī (1993). Sementara itu, puisi wa-Tāba al-Qalb diambil dari al-Majmū'ah al-Kāmilah (kumpulan antologi) Fārūq Juwaydah (1991).

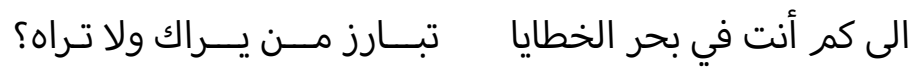

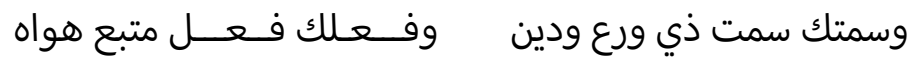

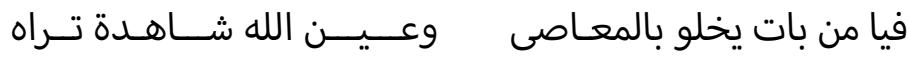

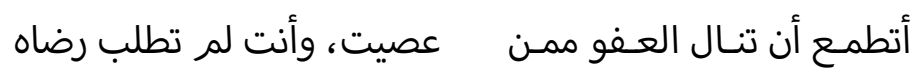

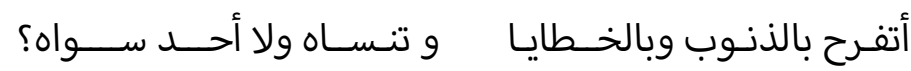

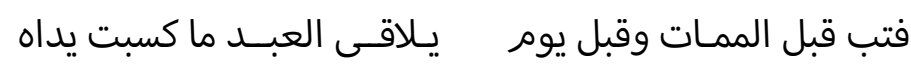

Sampai kapan kau ada dalam lautan kesalahan

kau menantang ia yang melihatmu, sementara kau tidak dapat melihat-Nya?

Dan jalanmu cara berjalan orang yang warak dan religius

sementara perilakumu mengikuti hawa nafsu

Maka wahai orang yang bergelut dalam maksiat sedangkan mata Allah adalah saksi, kau mengetahui-Nya

Apa kau berharap mendapat ampunan dari orang yang

kau maksiati, dan kau tidak meminta ridha-Nya

Senangkah engkau atas dosa dan kesalahan?

dan kau melupakan dan tak seorang pun yang melihat-Nya

Maka taubatlah sebelum mati dan sebelum hari seorang hamba mendapati apa yang diperbuat tangannya

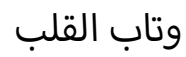

$$
\begin{aligned}
& \text { *** } \\
& \text { وظللت ابحث عنك بين الناس تنهرني خطايا } \\
& \text { وسنون عمري في زحام الحزن تتركني شظايا } \\
& \text { في كل درب من دروب الارض من عمري ... بقايا } \\
& \text { وعلى جدار الحزن صاح اليأس فارتعدت درن دمري الإيا } \\
& \text { ودفنت في أنقاد عمري أجمل الاحلام يبكيها صبايا } \\
& \text { حتى رأيتك بين أعماقى وجودا ... في الحنايا } \\
& \text { من كان يا عمري يصدق أنني } \\
& \text { يوما أضعت العمر أبحث عن هوايا }
\end{aligned}
$$




$$
\begin{aligned}
& \text { قد كان في قلبي يعيش } \\
& \text { وكان يسخر من خطايا؟ } \\
& * * * \\
& \text { لا تعجبني ان قلت اني قد رأيتك } \\
& \text { قبل أن تأتي الحياة } \\
& \text { وبأنني يوما عشقتك في ضمير الغيب } \\
& \text { سرا ... لاأراه } \\
& \text { كم تاه عقلي في دروب الحب } \\
& \text { وانتحرت ... خطاه } \\
& \text { كم عاش ينبش في بقايا اليأس } \\
& \text { يسأل عن هواه } \\
& \text { لكن قلبي كان يصمت لكان } \\
& \text { كان يدرك منتهاه } \\
& \text { فلقد أحبك أن تأتي الحياة } \\
& \text { *** } \\
& \text { عاتبت قبل كيف يتركني وحيدا في الدروب } \\
& \text { كم ظل يخدعني فليحملني الضلال الذنوب } \\
& \text { قد كنت في قلبي } \\
& \text { ولم أعرف سراديب القلوب } \\
& \text { غني أضعت العمر معصية } \\
& \text { وجئت الأن عندك كي أتوب } \\
& \text { وأمام بابك جئت أحمل توبتي } \\
& \text { لا حب غيرك ... لا ضلال ... ولا ذنوب !! }
\end{aligned}
$$

Dan Hati Itu Bertobat

$* * *$

Aku masih mencari engkau di antara manusia aku disalahkan dosa-dosaku

Dan tahun-tahun hidupku di tengah kesedihan aku diabaikan serpihan-serpihanku

Pada setiap jejak dari umurku di bumi... sisa-sisaku

Dan pada jendela kesedihan putus asa berteriak maka menggigil darahku

Dan aku mengubur dalam puing-puing hidupku dari mimpi terindah ditangisi masa kecilku

Hingga aku melihat-Mu ada di lubuk hatiku.. dalam rasa sayangku

Siapakah, hai kekasih-Ku, yang percaya bahwa aku

Suatu hari aku kehilangan hidupku dalam mencari cintaku

Sungguh, ia telah bersemayam di hatiku

Dan ia mengejek dosa-dosaku. 
Jangan heran jika kukatakan bahwa aku telah melihat-Mu

Sebelum kehidupan ini

Dan suatu hari, aku merindukan-Mu dalam hati nurani

Diam-diam... aku tak menyadarinya

Betapa tersesatnya akalku pada jalan cinta

Dan jejaknya telah bunuh diri

Berapa lama dia hidup menggali sisa-sisa keputusasaan

Ia menanyakan cinta-Nya

Akan tetapi hatiku telah membisu

Ia telah mengetahui tempat bernaungnya

Maka sesugguhnya, aku telah mencintai-Mu jauh sebelum kehidupan ini

***

Aku menyalahkan hatiku bagaimana mungkin ia membiarkanku seorang diri di jalanan

Berapa bayangan telah menipuku, lalu aku dibawa kesesatan kepada dosa-dosa

Sungguh Engkau telah ada di dalam hatiku

Dan aku tidak tahu lorong-lorong hati

Sesungguhnya, aku menyia-nyiakan usia dalam maksiat

Dan sekarang aku datang kepada-Mu untuk bertaubat

Dan di depan pintu-Mu aku membawa serta taubatku

Tak ada cinta selain-Mu, tak ada kesesatan, dan tak ada dosa-dosa

\section{B. Intertekstualitas Puisi al-Hallaj dan Puisi $W a$-Tāba al-Qalb Fārūq Juwaydah}

1. Kesamaan Tema

Secara garis besar, tema puisi al-Hallāj ini berupa teguran kepada yang lalai di dunia dan ajakan untuk mencintai Tuhan. Sebagaimana telah dijelaskan, al-Hallāj hidup pada masa pemerintahan Abbasiyah yang juga turut mengembangkan dunia kesusastraan, termasuk puisi, prosa, dan sebagainya. Saat itu, selain pujian, seruan kezuhudan menjadi tema utama bagi sekelompok penyair. Sebut saja Rabī'ah al-'Adāwīyah yang terkenal dengan puisi cinta $(a l-\not ̧ u b b)$ dan Abū al-'Atāhiyah yang terkenal dengan puisi asketis (al-mutashā'im). Keduanya dianggap sebagai penyair yang konsisten mengajak manusia untuk menjauhkan diri dari perilaku maksiat dan kehidupan mewah. Mereka juga kerap mengajak untuk hidup dalam kesederhanaan, menyiapkan bekal untuk akhirat.

Menurut al-Ghazālī, manusia memiliki bakat untuk menjadi penjahat atau jadi bijaksana. Dengan kata lain, manusia sangat potensial untuk menjadi manusia yang sempurna (insān kāmil) atau menjadi penjahat yang paling buas dibandingkan binatang. Oleh karena itu, hal pertama yang mesti diperhatikan adalah masalah hati. Hati manusia yang berfungsi sebagai cermin bisa menangkap cahaya gaib hanya jika ia tidak tertutup oleh kotoran-kotoran keduniaan. Dalam konsep tasawuf, yang dimaksud dengan dunia adalah segala sesuatu selain Tuhan (Simuh, 2018).

Fenomena pasang-surut kehidupan manusia itulah yang ingin disampaikan al-Hallāj dalam puisinya. Sebab, demikian itu lazim terjadi dalam dinamika kehidupan manusia selama di dunia. Untuk mengatasi kecenderungan melakukan perbuatan-perbuatan yang mengarah kepada kejahatan atau maksiat, seorang manusia sepatutnya mengingat akan keberadaan Tuhan yang selalu memperhatikan segala perbuatan hamba-hamba-Nya. Dalam kepercayaan Islam, ada dua Malaikat yang ditugaskan untuk mencatat perbuatan baik dan buruk yang dilakukan manusia. al-Hallāj 
bermaksud untuk mempertanyakan sekaligus memberikan saran kepada manusia untuk bertaubat kepada Tuhan. Tema tersebut dapat dilihat pada awal-awal bait puisinya.

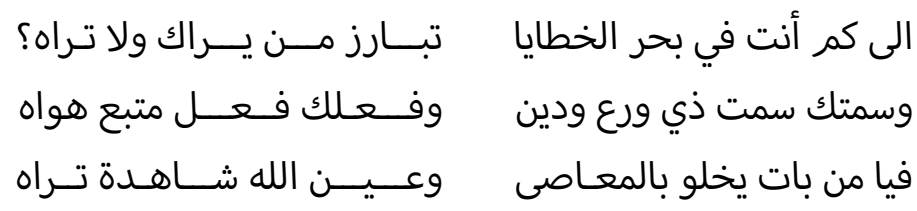

Sampai kapan kau ada dalam lautan kesalahan

kau menantang ia yang melihatmu, sementara kau tidak dapat melihat-Nya?

Dan jalanmu cara berjalan orang yang warak dan religius

sementara perilakumu mengikuti hawa nafsu

Maka wahai orang yang bergelut dalam maksiat

sedangkan mata Allah adalah saksi, kau mengetahui-Nya

Puisi wa-Tāba al-Qalb karya Fārūq Juwaydah, dilihat dari gagasan dan ungkapannya, secara intertekstual menunjukkan persamaan dan pertalian dengan puisi al-Hallāj, yakni sama-sama menyinggung kesadaran akan eksistensi Tuhan dalam kaitannya dengan agama. Meskipun demikian, terdapat perbedaan yang menunjukkan kepribadian masing-masing dalam menanggapi masalah yang sama. Masalah keagamaan menjadi tema yang umum diangkat oleh para penyair Arab modern, termasuk Fārūq. Sebagaimana menurut Munef Abdullah Ahmed dkk (2019), dalam perpuisian Arab modern, selain cinta, sosial dan politik, tema religi (Islam) memang menjadi salah satu tema yang sering diangkat oleh sebagian penyair. Fārūq dalam puisinya menyerukan tentang pentingny kesadaran akan eksistensi Allah. Hal ini dapat dilihat pada potongan puisi berikut.

$$
\begin{aligned}
& \text { حتى رأيتك بين أعماقى وجودا .. في الحنايا } \\
& \text { من كان يا عمري يصدق أنني } \\
& \text { يوما أضعت العمر أبحث عن هوايا } \\
& \text { قد كان في قلبي يعيش العمن }
\end{aligned}
$$

Hingga aku melihat-Mu ada di lubuk hatiku. dalam rasa sayangku

Siapakah, hai kekasih-Ku, yang percaya bahwa aku

Suatu hari aku kehilangan hidupku dalam mencari cintaku

Sungguh, ia telah hidup di hatiku

Puisi al-Ḥallāj dan puisi Fārūq sama-sama mengingatkan tentang kesadaran manusia agar kembali mengintrospeksi tujuan mereka hidup. Manusia, terlebih seorang Mukmin, dalam ajaran Islam dituntut untuk tidak melakukan perbuatan yang dilarang. Sebagaimana ajaran Nabi, setiap orang Mukmin, jika berbuat maksiat, akan muncul sebuah noktah hitam yang mengotori hatinya. Semakin banyak ia berbuat maksiat, semakin banyak pula noktah hitam yang menutupi hatinya (Bagir, 2019).

Dari substansi tema puisi al-Ḥallāj maupun Fārūq di atas, dapat dikatakan bahwa baik al-Ḥallāj maupun Fārūq berharap manusia selama di dunia tidak boleh berlaku semena-mena, dalam artian ia harus mempertimbangkan setiap perbuatan yang dilakukannya sebab pada hari penghitungan amal akan dipertanggungjawabkan. Selain itu, kesadaran akan eksistensi Tuhan perlu diperhatikan agar 
manusia dapat meminimalisir kecenderungan-kecenderungan dalam melakukan tindak kejahatan, terutama mengerjakan dosa besar dan tidak bertaubat. Haidar Bagir (2019) menjelaskan betapa pentingnya bagi manusia untuk selalu berhati-hati sepanjang waktu. Manusia perlu memperhatikan segala jenis tindakan yang hinggap dalam pikiran dan hatinya. Untuk itu, sebelum berbuat, seorang manusia dituntut untuk berpikir dan menyelidiki semua pikiran dan perasannya. Lebih lanjut, manusia diminta berjuang untuk mengendalikan dan waspada atas hasrat nafsu jangan sampai mereka menurutinya.

\section{Perbedaan Tipografi}

Kedua puisi tersebut, dilihat dari segi bentuk (tipografi), tentunya memiliki perbedaan. Hal tersebut dikarenakan bahwa puisi Arab klasik telah mengalami berbagai macam perkembangan, terutama dari segi bentuknya. Dalam konteks ini, bentuk puisi al-Hallāj masih mengikuti bentuk puisi tradisional Arab atau yang lazim disebut qașidah. Sukron Kamil (2009) mengatakan, dalam khazanah kesusastraan Arab, puisi tradisional sering disebut dengan puisi klasik (qadim), atau sering juga disebut puisi multazim (biasa atau konvensional, terikat aturan lama). Puisi ini adalah puisi Arab yang terikat prosodi ('arüd), seperti metrum (wazn/baḥr) dan rima (qäfiyab), yang secara umum susunan baris (enjambemen)-nya berbentuk qasidah dengan dua baris sejajar. Kāmil Mușțafá alShaybī (1993) dalam Sharḅ Dīwān al-Hallāj mengategorikan puisi al-Hallāj tersebut ke dalam puisi yang ber-baḅr wäfir.

Jika dilihat dari kaca mata sejarah, rentang masa hidup al-Hallāj berada di bawah Dinasti Abbasiyah, yaitu antara tahun 750-1258 M. Pada masa itu, puisi menjadi sebuah wadah atau alat untuk mengekspresikan budaya mereka (Weidner, 2017). Tidak hanya puisi, karya sastra secara umum kala itu mengalami perkembangan yang sangat signifikan. Penerjemahan karya sastra lain ke dalam bahasa Arab juga menjadi prioritas. Hal itu didukung pula oleh Khalifah al-Ma'mūn yang mendirikan bayt al-hikmah sebagai perpustakaan, lembaga penerjemahan, dan pusat penelitian. Dari kebijakan positif tersebut, lahirlah penulisan berbagai jenis karya tulisan, seperti prosa, surat, anekdot, dan cerita pendek (Musa, 2019).

Di antara penyair yang masyhur pada masa Dinasti Abbasiyah, yaitu Abū Nuwās (747-803 M), Imam Shāfi ī (764-820 M), al-Jāḥiz (781-869 M), al-Mutanabbī (875-965 M), Ibn al-Muqaffa‘ (720-759 M), al-Buhturī (820-897 M), al-Ma'arrī (973-1058 M), dan penyair sufi perempuan Rabī'ah al-'Adawiyah (713-801 M). Puisi-puisi para penyair top Dinasti Abbasiyah tersebut masih mempertahankan dan menggunakan bentuk qașidah atau sajak-sajak yang panjang. Namun, di sii lain juga terjadi perubahan dalam tema, yang meliputi hiburan, zuhud, filsafat, minuman keras, pujian kepada kaum laki-laki, hingga tema tentang alam eskatologis yang merupakan refleksi sejarah panjang masyarakat Abbasiyah yang plural.

Formula puisi Arab yang umumnya digunakan pada periode Abbasiyah adalah satu metrum dan satu rima. Bentuk ini telah digunakan pula oleh penyair Arab pra-Islam (jābilīyah). Tipografi puisi ini tampak selalu konsisten yang ditulis mulai dari pinggir kanan, dan sifatnya pun panjang ( $\mathrm{Al}$ Hinduan et al., 2020). Adapun tipografi qașìdah al-Ḥallāj yang menggunakan bentuk puisi yang trend kala itu, seperti berikut ini.

$$
\text { الى كم أنت في بحر الخطايا تبــارز من يـراك ولا تراه؟ }
$$


Tipografi qașidah al-Hallāj di atas adalah tipografi puisi tradisional Arab yang mengutamakan aspek metrum (baḅr) dan rima (qäfiyab), ditulis dari kanan ke kiri dan sifatnya panjang. Huruf terakhir pada bait kedua dan keempat di akhir dengan hurup yang sama. Jenis babr yang digunakan dalam qașīah al-Hallāj tersebut adalah baḥr wäfir dengan wazan,

مفاعلتن مفاعلتن مفاعل مفاعلتن مفاعلتن مفاعل

Kemudian, tipografi puisi Fārūq bertolak belakang dari puisi al-Hallāj. Tipografi yang digunakan Fārūq bukan lagi bentuk tradisional yang terikat dengan 'arūọ. Akan tetapi, Fārūq menggunakan tipografi puisi bebas. Puisi bebas Arab (al-shi'r al-burr) merupakan puisi yang tidak terikat prosodi ('arüd), seperti metrum (wazn/baḥr) dan rima (qāfiyah), yang secara bentuk terkadang mendekati gaya prosa sastra dan susunan baris (enjambemen)-nya tidak dalam bentuk qașidah dengan dua baris sejajar, tetapi tersusun ke bawah (Kamil, 2009). Ini sebagaimana yang terlihat pada potongan puisi Fārūq berikut.

$$
\text { وسنون وظللت ابحث عنك بين الناس تنهرني خطايا }
$$

Tipografi puisi di atas jelas berbeda dari bentuk puisi konvensional. Tidak lagi berbentuk sajak, melainkan tampak seperti puisi-prosa. Selain itu, tidak lagi menekankan pada aspek metrum dan rima, melainkan cenderung mengutamakan maknanya. Puisi Fārūq termasuk ke dalam puisi bebas dan berbeda dengan qașīdah al-Hallāj yang masih kokoh dengan karakter konvensionalnya. Puisi ini tidak lagi konsisten dari kanan ke kiri, melainkan dari atas ke bawah.

Terkait asal-muasal kemunculan tipografi atau bentuk puisi Arab bebas, penyair yang pertama kali dinggap berhasil melepaskan dan menghancurkan pola qașīdah atau puisi tradisional adalah Khalīl Muțrān. Sebagai penyair aliran neo-klasik, Muṭān memandang puisi sebagai produk pikiran batin (walìd al-fikr al-däkhilìyah), dan pikiran tidak dapat dimanifestasikan dalam bentuk yang tersistem dan kompleks. Dari argumen ini, penyair neo-klasik mulai melepaskan diri dari model puisi konvensional dan menggunakan model Barat, khususnya Inggris. Selain itu, model puisi ini juga tidak lagi mementingkan aspek-aspek baläghah, melainkan membuat bentuk yang mudah dan simpel (al-'Ațawī, 2016). Menurut Adnan Haydar (1981), Jubrān Khalīl Jubrān (Kahlil Gibran) dianggap sebagai dalang yang mendobrak tradisi puisi Arab modern.

Puisi bebas (al-hurr atau al-mursal) menjadi bentuk standar dalam puisi arab modern di kalangan sastrawan diaspora (al-Mabjar), di antaranya: Jubrān (1883-1931), Mīkhā’̄il Nu'aymah (1889), Īliyā Abū Māọī (1894-1957), dan lainnya. Adapun bentuk pengungkapan sastra diaspora umumnya cenderung lebih bebas dan terlepas dari kaidah-kaidah puisi tradisional yang hanya menekankan pada aspek wazan dan sajak/matra.

\section{Perbedaan Redaksi}

Sebagai karya transformasi, jelas bahwa Fārūq menciptakan puisi wa-Tāba al-Qalb sesuai dengan pandangannya sendiri, dan horison atau harapannya sendiri pula. Jika Fārūq menyusun karyanya persis seperti qașidah al-Hallāj, maka tindakan tersebut dapat dikategorikan sebagai plagiasi atau 
menjiplak karya orang lain. Oleh karena itu, dalam hal ini perlu diuraikan letak perbedaan redaksi pada kedua karya tersebut. Pertama, al-Hallāj menggunakan bentuk interogatif atau tanda tanya dengan disebutkannya huruf istifhām sebanyak tiga kali dalam puisinya.

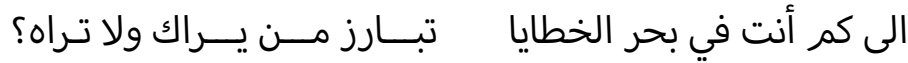

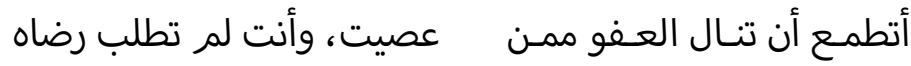

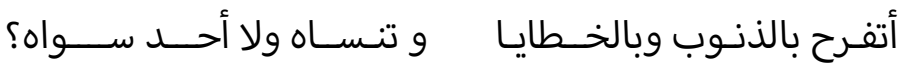

Sementara itu, puisi Fārūq lebih didominasi bentuk narasi dan bernuansa pembelaaan.

$$
\text { وفي كل درب ونللت ابحث عنك بين الناس تنهرني خطايا }
$$

Kedua, al-Hallāj ketika mengawali puisinya seakan-akan secara spontanitas menegur mitra bicaranya tanpa alasan yang detail terkait apa yang sebenarnya dilakukan oleh mitra bicara tersebut. Dalam hal ini, al-Hallāj mengekspresikan gagasannya secara padat. Sementara itu, Fārūq memulai puisinya dengan pembelaan bahwa ia tidak lupa akan eksistensi Tuhan, melainkan masih dalam usaha pencarian untuk menemukan Tuhan yang dimaksud. Spontanitas al-Hallāj dapat dilihat dari penggunaan kalimat interogatif (istifhām) di awal puisinya, seolah-olah merepresentasikan telah terjadi dialog sebelumnya. Selain itu, nada (tone) al-Hallāj ketika mengutarakan pemikiran di dalam puisinya tampak tegas, langsung kepada inti, dan tidak mendayu-dayu. Sebaliknya, Fārūq menguraikan permasalahan yang dihadapinya secara detail. Ia memberikan penjelasan ibarat seseorang yang merasa telah melakukan kesalahan dan akan menerima hukuman dari seseorang yang marah. Fārūq juga melakukan pembelaan terhadap dirinya sendiri dengan mengatakan bahwa ia menyadari akan adanya eksistensi Tuhan, dan mencintainya. Meskipun demikian, ia juga tidak dapat mengabaikan cintanya kepada manusia. Cintanya kepada manusia melebihi cintanya kepada Tuhan. Oleh karena itu, pada bagian akhir puisinya, ia mengungkapkan penyesalannya di mana kecintaannya kepada manusia dapat melalaikannya dari pada cinta yang sebenarnya, yaitu cinta kepada Tuhan yang telah menciptakan dirinya.

Ketiga, subjek tampak mendominasi dalam keseluruhan bait qașidah al-Hallāj. Hal tersebut terlihat dari tidak adanya kesempatan bagi objek untuk melakukan pembelaan meskipun sekadar berbicara. Sebaliknya, Fārūq melakukan penyeimbangan dengan beberapa kali memunculkan interaksi dialogis dengan lawan bicara di dalam puisinya. Selain itu, kedua puisi tersebut memiliki persamaan dalam hal minimnya penggunaan metafora sehingga untuk memperoleh maknanya cukup mudah. Pada qașidah al-Hallāj ditemukan kalimat "baḥr al-khațāyā" (lautan kesalahan) yang mengindikasikan bahwa lawan tuturnya adalah pendosa besar. Sementara itu, dalam puisi Fārūq terdapat ungkapan "amāma bābika" (di depan pintumu) yang makna kontekstualnya menunjukkan bahwa manusia itu telah bersimpuh di hadapan Tuhan-Nya. 


\section{Persamaan Genre}

al-Hallāj merupakan sosok seorang sufi agung yang dikenal berkat pernyataan kontroversialnya, yaitu "Anā al-Haqq" yang berarti Akulah representasi kebenaran dari Sang Khalik (al-Shaybī, 1998). Imam al-Ghazālī menyebut al-Ḥallāj sebagai seorang orang berilmu ('ārif) yang telah sampai pada langit kebenaran (Makārim, 2016). Dalam pandangan Soebardi (dalam Feener, 1998), al-Ḥallāj adalah Syaikh Siti Jenar dalam versi Jawa (Nusantara). Salah satu konsep yang digaungkannya ketika masih hidup adalah al-hulūl. Di dalam ajaran al-ḥulūl dikatakan bahwa seseorang dapat memfanakan dirinya ke dalam Tuhan, yakni ia harus mensucikan roh yang ada dalam dirinya terlebih dahulu. Konsep al-ḅulül-nya al-Hallāj seringkali atau bahkan telah mendominasi semua karya-karya puisinya (Tualeka, 2017).

Keterangan di atas akhirnya mengantarkan pada simpulan bahwa qașidah al-Hallāj merupakan bagian dari puisi transendental atau puisi sufistik. Puisi sufistik sebagai sastra transendental adalah perwujudan seorang penyair yang sadar sebagai makhluk spiritual dan selalu berusaha mengungkapkan dirinya. Tanpa dimensi spritual, manusia tidak akan pernah bisa menyempurnakan kemanusiaannya. Transendensi sebenarnya tidak harus berarti kesadaran terhadap ketuhanan secara agama saja, tetapi bisa juga kesadaran terhadap makna apa saja yang melampaui batas kemanusiaan. Para penyair sufi memandang dunia sebagai sesuatu yang tak boleh disia-siakan dan memiliki tujuan yang mulia, yaitu sebagai ladang untuk bercocok tanam dan sebagai pasar untuk menggelar barang dagangan. Meskipun demikian, mereka juga menolak sikap terikat kepada dunia (Hadi, 1999; Kuntowijoyo, 2019).

Selanjutnya, baik qașīdah al-Hallāj maupun puisi Fārūq sama-sama mengungkapkan masalah kemanusiaan dan hubungannya dengan Tuhan. Ketika kita membaca qașidah al-Hallāj, umumnya akan mengantarkan manusia kepada perenungan mendalam tentang eksistensi Tuhan yang tidak dapat diabaikan. Hal tersebut dapat dilihat dari respon Fārīq melalui puisinya. Puisi wa-Tāba alQalb seakan menjadi negasi terhadap pesan-pesan spritual yang dicanangkan oleh al-Ḥallāj dalam qașidah-nya.

$$
\text { ولم أعرف سراديب القلوب قلب }
$$

Pada potongan puisi di atas, Fārūq melukiskan apa yang diharapkan oleh al-Hallāj dari manusia, yaitu penyatuan diri manusia dengan Tuhan. Melalui ungkapan tersebut, Fārūq dianggap berhasil menunjukkan konsep al-ḅulül. Penyatuan tersebut tentunya dapat dilakukan melalui proses yang bisa dikatakan cukup sulit. Jika sifat ketuhanan yang ada pada diri manusia dapat bersatu dengan sifat kemanusiaan pada diri Tuhan, maka terjadilah b̧ulül. Namun, untuk mencapai tingkatan tersebut, manusia harus terlebih dahulu menghilangkan sifat-sifat kemanusiaannya melalui proses fana (Hamkah, 2018).

\section{Karya Hipogram dan Karya Transformasi}

Sebelum menguraikan mana karya yang menjadi hipogram dan karya transformasi, perlu kiranya dijelaskan sedikit tentang apa yang sebenarnya diinginkan oleh al-Hallāj kepada manusia. Ia menawarkan agar manusia kembali kepada kesunyian, karena di sana, hakikat mutlak ditemukan kembali. Manusia harus kembali sadar akan kediriannya. Dengan begitu, hakikat sejati disadari 
(Miswari, 2019). Keinginan tersebut lalu direspon oleh Fārūq Juwaydah dalam puisinya wa-Tāba alQalb. Jadi, dengan uraian singkat ini, tampaklah bahwa makna puisi Fārūq menjadi lebih jelas dan dapat lebih penuh tergali bila disejajarkan secara intertekstual dengan qașidah al-Hallāj.

Sebagaimana yang telah dijelaskan sebelumnya, dalam kajian intertekstual perlu ditentukan terlebih dahulu mana yang menjadi teks transformasi dan mana teks hipogram. Teks hipogram adalah teks yang dijadikan sebagai acuan dalam pengambilan ide, gagasan, ataupun dasar dari penciptaan teks atau karya baru. Sementara itu, teks transfromasi adalah teks yang baru muncul belakangan atau teks yang menjadi respon dari teks sebelumnya. Dalam penelitian ini, yang menjadi teks hipogram adalah qașīdah al-Hallāj. Penentuan qașìdah al-Hallāj sebagai hipogram tidak lain berdasarkan pada tahun terbitnya, yaitu pada abad $10 \mathrm{M}$. Selanjutnya, puisi Fārūq ditetapkan sebagai teks transformasi berupa respon dari qạ̦īah al-Hallāj. Karya Fārūq ini tidak lagi sekadar repetisi, melainkan telah mengalami ekspansi dari qașìdah al-Hallāj.

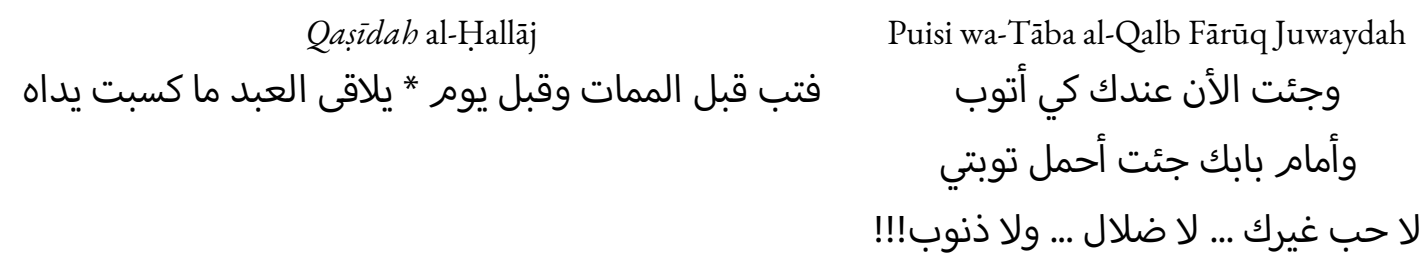

Dua kutipan di atas menunjukkan proses interteks melalui pertimbangan (deliberation). Dengan kata lain, Faruq menulis puisinya dengan tetap mempertimbangkan eksistensi dari qașidah al-Hallāj. al-Hallāj menggunakan piranti perintah (amar) فتب (maka bertaubatlah), lalu dikemudian direspon oleh Fārūq dengan ungkapan جئت الأن كي أتوب (aku datang untuk bertaubat). Kedua penyair melalui dua puisi tersebut seolah-olah terlibat dalam interaksi percakapan. Adapun yang menjadi partisipannya adalah Al-Hallaj sebagai penutur, penegur atau O1, dan Fārūq berperan sebagai lawan tutur, yang ditegur, dan $\mathrm{O} 2$.

\section{Simpulan}

Berbagai uraian yang telah dijelaskan, dapat ditarik kesimpulan sebagai berikut. Pertama, karya sastra yang terbit lebih dulu berpengaruh terhadap munculnya karya sastra yang baru. Kedua, karya sastra lama menjadi hipogram bagi karya sastra transfromasi. Ketiga, kajian intertekstual dalam penelitian ini, yang menjadi teks hipogram adalah qașìdah al-Hallāj, sedangkan yang menjadi karya transformasi adalah puisi wa-Tāba al-Qalb karya FārūqJuwaydah. Keempat, puisi Fārūq menjadi respon terhadap puisi al-Hallāj. Proses interteks qașīah al-Hallāj dengan puisi Fārūq Juwaydah dilakukan dengan cara pertimbangan (deliberation). Fārūq masih melihat qașìdah al-Hallāj sebagai bahan atau acuan dalam mengarang puisinya. Hal tersebut dilihat dari pemilihan kata yang sama, yaitu تب وأتوب.

Penelitian interteks ini kembali menegaskan bahwa makna atau subtansi dari karya yang baru muncul tidak selalu independen. Singkatnya, kemunculan atau kelahirannya dapat dipastikan karena mendapat pengaruh dari karya-karya yang telah muncul sebelumnya. Itulah yang terjadi antara qạ̦īah al-Hallāj dan puisi wa-Tāba al-Qalbyang ditulis oleh FārūqJuwaydah. Karya-karya al-Hallāj termasuk karya yang menarik dan berkualitas sastrawi. Karya sastra yang memiliki kualitas yang bagus tentunya tetap akan memiliki pengaruh yang kuat, meskipun sudah lama ditinggal oleh 
pengarangnya. Karya sastra tersebut akan dijadikan sebagai acuan untuk menciptakan karya-karya sastra yang baru. Akan tetapi, meskipun menjadikan karya sastra lama sebagai acuan, tentu sisi kreativitas seorang pengarang tidak dapat dikesampingkan begitu saja. Memang betul, ide yang diambil dari karya lama, akan tetapi rasa yang ditanamkan dalam karya baru tentu berbeda, karena pengarangnya juga adalah manusia yang berbeda.

\section{Daftar Rujukan}

Abdullah, A-S. (2009). Intertextuality and West African Arabic poetry: Reading Nigerian Arabic poetry of the 19th and 20th Centuries. Journal of Arabic Literature, 4O(3), 335-361. Retrieved from http://www.jstor.org/stable/20720593

Ahmed, M. A., Hasan, R. A., Ali, A. H., \& Mohammed, M. A. (2019). The classification of the modern Arabic poetry using machine learning. Telkomnika, 17(5), 2667-2674. doi:10.12928/telkomnika.v17i5.12646

Albay, M., \& Serbes, M. (2017). Intertextuality in the literature. International Journal of Social Sciences and Educational Studies, 3(4), 208-214. doi:10.23918/ijsses.v3i4p208

Al Hinduan, N., Tohe, A., \& Huda, I. S (2020). Karakteristik dan fungsi puisi Arab pada Masa transisi pemerintahan Dinasti Umayyah ke Dinasti Abbasiyah. Alsina: Journal of Arabic Studies, 2(1), 51-70. doi:10.21580/alsina.2.1.5127

Ansari, N. (2016). Shi'r Fārūq Juwaydah: Dirāsah uslūbīyah fī shi'rih al-multazam. Majallat alLughah al-'Arabiyah wa-Ādābihā 'Ilmìyah Muhakkamah, 12(1), 27-47. Retrieved from https://www.sid.ir/fa/journal/ViewPaper.aspx?id=320638

Ansari, M. A. H. (2000). Husayn ibn Manșūr al-Hallāj: Ideas of ecstatic. Islamic Studies, 39(2), 291320. Retrieved from https://www.jstor.org/stable/23076104

al-'Ațawī, M. I. (2016). al-Adab al-'Arabì al-ḥadìth. n.p.: Shabakah al-Alūkah.

Bagir, H. (2019a). Mengenal tasawuf. Jakarta: Noura Books.

Bagir, H. (2019b). Semesta cinta: Pengantar kepada pemikiran Ibn 'A rabi. Jakarta: Noura Books.

Batmang. (2019). Ekspresi Amir Hamzah dan Chairil Anwar dalam puisi-puisi percintaan. Kandai, 15(2), 185-200. doi:10.26499/jk.v15i2.939

El Shirazy, H. (2014). Berdakwah dengan puisi: Kajian intertekstual puisi-puisi religius Taufiq Ismail. At-Tabsyir: Jurnal Komunikasi Penyiaran Islam, 2(1), 35-56. doi:10.21043/attabsyir.v2i1.462

Endraswara, S. (2011). Metodologi penelitian sastra: Epistemologi, model, teori dan aplikasi. Yogyakarta: CAPS.

Faruq. (2014). Metode penelitian sastra: Sebuab penjelajaban awal. Yogyakarta: Pustaka Pelajar.

Feener, R. M. (1998). A re-examination of the place of al-Hallāj in the development of Southeast Asian Islam. Bijdragen tot de taal-, Land-en Volkenkunde Journal Of Humanities and Social Sciences of Southeast Asia and Oceania, 154(4), 571-592. doi:10.1163/22134379-90003885

Hadi A. W. M. (1999). Kembali ke akar kembali ke sumber: Esai-esai sastra profetik dan sufistik. Jakarta: Pustaka Firdaus.

Haidar, A. (1981). What is modern about modern Arabic poetry? Al-'Arabiyya, 14(1), 51-58. Retrieved from https://www.jstor.org/stable/43195490 
Hamkah, Z. (2018). Husain Al-Hallaj dan ajarannya. Ash-Shahabah, Jurnal Pendidikan Studi Islam, 4(2), 183-188. Retrieved from https://journal-uimmakassar.ac.id/index.php/ASH/article/view/226

Jabrohim (ed). 2017. Teori penelitian sastra. Yogyakarta: Pustaka Pelajar.

Juwaydah, F. (1991). al-Majmūah al-kāmilah. Cairo: Markaz al-Ahrām li-al-Tarjamah wa-al-Nashr. Kamil, S. (2009). Teori kritik sastra Arab klasik dan modern. Jakarta: Rajawali Pers.

Khezri, A., \& Hamdi, M. (2020). Tajalliyāt al-nustūlūjīyah wa-ẓawāhiruhā fī shi'r Fārūq Juwaydah. Majallat al-'Ulūm al-Ijtimā'ìyah wa-al-Insānīyah, 13(2), 137-153. Retrieved from https://www.asjp.cerist.dz/en/article/141922

Kuntiwijoyo. (2019). Maklumat sastra profetik. Yogyakarta: Diva Press.

Madās, A. (2004). Taḥlīl al-khițāb al-shi'r fì manzūr al-lisānìyāt al-nașsīyah: Dirāsah tațbiqqīyabliqașidatay al-Masā' li-İliyā Abū Mādì wa-Qāri'at al-Finjān li-Nizār al-Qabbānī (Master's thesis, Université Mohamed Khider Biskra, Algeria). Retrieved from http://thesis.univbiskra.dz/2177/

Makārim, S. (2016). al-Hallāj fì mà warā'a al-ma'ná wa-al-khatṭ wa-al-lawn. London: Riad ElRayyes Books.

Miswari. (2019). Cara gila jatuh cinta: Analisa qasidah dan muqataat Mansur Al-Hallaj. Al-Mabhats: Jurnal Penelitian Sosiologi Agama, 4(1), 51-74. Retrieved from https://ejurnal.iainlhokseumawe.ac.id/index.php/al-mabhats/article/view/284

Mousa, M. A. (2013). Literary intertextuality and its Meaning in the Arabic modern criticism. Research Journal of International Studies, 26, 142-147.

Mukarromah, O. (2015). Ittihad, hulul, dan wahdatul wujud. Tazkiya: Jurnal Keislaman, Kemasyarakatan, dan Kebudayaan, 16(1), 129-146. Retrieved from http://jurnal.uinbanten.ac.id/index.php/tazkiya/article/view/212/214

Musa, I. A. (2019). Arabic literature in Abbasid Period. Abuja: National Open University of Nigeria. Muzakka, M. (2018). Hubungan intertekstualitas syair Paras Nabi dan hikayat Nabi Bercukur. Nusa: Jurnal Ilmu Bahasa dan Sastra, 13(3), 341-350. doi:10.14710/nusa.13.3.341-350

Naemi, Z. \& Zaemohammedi, S. (2014). Tajalliyāt al-Muqāwamah al-Filisțīnīyah fī Shi'r Fārūq Juwaydah. Naqd Adab 'Arabi, 5(1), 173-208. Retrieved from https://www.sid.ir/fa/journal/ViewPaper.aspx?id=322614

al-Ni'āmī, M. M. (2012). Tajalliyāt al-tanāṣ fī dīwān Mukhtārāt min Shi'r Intifāḍat al-Aq̣̦á, al-juzz al-awwal. Majallat al-jāmi'ah al-Islāmìyah li-al-Buhüth al-Insānīyah, 20(2), 99-141. Retrieved from https://journals.iugaza.edu.ps/index.php/IUGJHR/article/view/716

Pradopo, R. D. (2019). Pengkajian puisi. Yogyakarta: Gadjah Mada University Press.

Ratih, R. (2017). Teori dan aplikasi semiotika Michaeil Riffaterre. Yogyakarta: Pustaka Pelajar.

Ratna, N. K. (2015). Teori, metode, dan teknik penelitian sastra. Yogyakarta: Pustaka Pelajar.

Roshanfar, K., \& Rakhshadehnia, S. A. (2010). Qinā' al-Ḥallāj fĩ al-Shi'r al-'Arabī al-Mua'ṣir: Ṣalāh 'Abd al-Ṣabūr wa-'Abd al-Wahhāb al-Bayātī Numūdhajān. Majallat 'Ulūm Insānī, 17(3), 1328. Retrieved from https://www.sid.ir/fa/journal/ViewPaper.aspx?ID=196773

Sholihah, A., \& Kaulin, F. (2017). Hypatia dalam novel Azazil dan film Agora: Kajian sastra bandingan. Al-Ma'rifab: Jurnal Budaya, Babasa, dan Sastra Arab, 14(2), 102-113. doi:10.21009/almakrifah.14.02.07 
Simuh. (2018). Sufisme Jawa: Transformasi tasawuf Islam ke mistik Jawa. Yogyakarta: Narasi \& Promethea.

Syafi'i, K. (2003). Tafakur di ujung cinta. Yogyakarta: Pustaka Pelajar.

al-Shaybī, K. M. (Ed.). (1993). Sharḥ Dīwān al-Hallāj. Berlin: Manshūrāt al-Jamal.

al-Shaybī, K. M. (1998). al-Silah bayna al-tașawwuf wa-al-tashayyu'. Cairo: Dār al-Ma'ārif.

Taufiq. (2014). Al Hallaj sufi mati di tiang salib: Kajian filsafat bebas nilai. Pena: Jurnal Ilmu Pengetabuan dan Teknologi, 26(1), 23-34. Doi:10.31941/jurnalpena.v26i1.106

Tualeka, M. W. N. (2017). Kajian kritis tentang tasawuf al-Hallaj. Al-Hikmab:Jurnal Studi Agamaagama, 3(2). Retrieved from http://journal.umsurabaya.ac.id/index.php/Ah/article/view/1046

'Uyūn al-Sūd, M. B. (Ed.). (2013). Dìwān al-Hallāj wa-ma' abu akbbār al-Hallāj wa-dhikr maqtal al-Hallāj li-Ibn Zanjī wa-kitâb al-Ṭawāsinn. Beirut: Dār al-Kutub al-'Ilmīyah.

Weidner, G. (2017). Popular literature in the Abbasid caliphate: How it represented and defined the culture of the Abbasid. University of Massachusetts Undergraduate History Journal, 1(2),19-32. doi:10.7275/R5CR5RH8 